\title{
Involvement of the Tyrosinase Gene in the Deposition of Cardiac Lipofuscin in Mice Association with Aortic Fatty Streak Development
}

Jian-Hua Qiao, * Carrie L. Welch, "* Pei-Zhen Xie, " Michael C. Fishbein, ${ }^{*}$ and Aldons J. Lusis *

${ }^{*}$ Department of Medicine, Department of Microbiology and Molecular Genetics and Molecular Biology Institute, and ${ }^{\ddagger}$ Department of Pathology, University of California, Los Angeles, California 90024; and $\$$ Department of Pathology,

Cedars-Sinai Medical Center, Los Angeles, California 90048

\begin{abstract}
Lipofuscin pigment, a terminal oxidation product, accumulates within cells during the normal aging process and under certain pathological conditions. We have analyzed a genetic cross between two inbred mouse strains, BALB/cJ and a subline of C57BL/6J, which differ in lipofuscin deposition. A comparison of the segregation pattern of cardiac lipofuscin with the albino locus $(c)$ on mouse chromosome 7 revealed complete concordance. Analysis of spontaneous mutants of the tyrosinase gene, encoded by the albino locus, confirmed that the tyrosinase gene itself controls lipofuscin formation. Genetic analysis of other strains indicated that one or more additional genes can contribute to the inheritance of lipofuscin. We also present evidence for an association between cardiac lipofuscin deposition and aortic fatty streak development in the mouse. (J. Clin. Invest. 1993.92:2386-2393.) Key words: atherosclerosis • lipid oxidation • albino locus $\bullet$ melanin $\bullet$ inflammation
\end{abstract}

\section{Introduction}

Using bright field illumination, lipofuscin pigment appears as irregular yellow-brown granules within cells in unstained tissue sections. The pigment consists of terminally oxidized polyunsaturated lipid and protein complexes, in associations involving Schiff base formation. Such complexes result in part from the reaction of malondialdehyde, a product of lipid peroxidation, with phospholipids, nucleic acids, or primary amino groups of proteins (1-3). Oxidative stress appears to play a key role in lipofuscin formation. For example, increases in oxygen and iron concentrations act synergistically to induce lipofuscin deposition in cultured rat myocytes $(4,5)$. Similarly, high intake of polyunsaturated fatty acids (6) or deficiency of antioxidants, such as vitamin $E(7,8)$, increases the rate of lipofuscin formation in tissues of experimental animals. In human nerve cells, a positive correlation between the deposition of lipofuscin and the activity of certain oxidative enzymes has been observed (9).

Lipofuscin can accumulate in a variety of tissues and cell types (10), and is associated in some cases with pathological

Address correspondence to Aldons J. Lusis, Ph.D., Division of Cardiology, Department of Medicine, University of California at Los Angeles, Los Angeles, CA 90024.

Received for publication 27 January 1993 and in revised form 25 June 1993.

J. Clin. Invest.

(C) The American Society for Clinical Investigation, Inc.

$0021-9738 / 93 / 11 / 2386 / 08 \$ 2.00$

Volume 92, November 1993, 2386-2393 conditions $(1,11)$. For example, varying amounts of lipofuscin occur in the myocardium of most adults. In myocardial fibers, the pigment accumulates around nuclei and is frequently associated with mitochondria. It has been suggested that the resulting nuclear damage may reduce the capacity for protein synthesis and mitochondrial replacement, thereby contributing to heart failure during stress (1). Lipofuscin also occurs in macrophages in atherosclerotic lesions; however, the significance of pigment deposition in fatty streaks and atherosclerotic plaques is unknown (11).

The tendency to form lipofuscin appears to be determined in part by genetic factors (12). We have previously reported that certain strains of mice develop lipofuscin on the aortic valve leaflets (13). We now show that cardiac lipofuscin is genetically determined among inbred strains of mice. We demonstrate that pigment formation is controlled by the tyrosinase gene, as well as one or more additional genes. Finally, we provide evidence for a link between the development of lipofuscin and early atherosclerotic lesions (fatty streaks).

\section{Methods}

Animals and diets. All strains of mice were purchased from The Jackson Laboratory (Bar Harbor, ME) except C57BL/10ScSnA and C3H/ DiSnA, which were obtained from Dr. Peter Demant (Amsterdam, The Netherlands). Genetic F1 and F2 crosses between strains BALB/ $\mathrm{cJ}$ and B6.C. $H-25^{c}$ were performed in our laboratory using B6.C. $H$ $25^{c}$ females and BALB/cJ males as parents. The congenic strain, B6.C. $H-25^{c}$, is identical with C57BL/6J except for a small region of mouse chromosome 1 containing the $H-25^{c}$ gene (14). Animals were fed either an atherogenic (ATH) ${ }^{1}$ diet (TD 90221; Food-Tek, Inc., Morris Plains, NJ), containing $15 \%$ (wt/wt) fat, $1.25 \%$ cholesterol, and $0.5 \%$ cholic acid, or standard rodent chow (Purina 5001; RalstonPurina Co., St. Louis, MO). All mice had free access to food and water and were housed in a temperature-controlled facility with a 12-h light and dark cycle. At the time of death, mice were in most cases between 4 and 6 mo old.

Histological analysis. Animals were sacrificed by cervical dislocation after anesthesia (Forane; Anaquest, Madison, WI). Mouse hearts, including the aortic root, were dissected and washed once in phosphate-buffered saline to remove blood. The basal portion of the heart and root of aorta were embedded in OCT compound (Miles Inc., Elkhart, IN) and frozen on dry ice. Serial $10-\mu \mathrm{m}$-thick cryosections of the heart tissue, covering the area between the appearance of the mitral

1. Abbreviations used in this paper: $\mathrm{AORV}$, aortic valve leaflets, aortic wall, and ostia of coronary arteries; ATH, atherogenic; ENDO, the endocardium of the four cardiac chambers, including the connective tissue associated with the aortic root anulus; MITV, mitral valve leaflets; PULV, pulmonary valve leaflets; RI, recombinant inbred; TRIV, tricuspid valve leaflets. 
valves to the disappearance of the aortic valves, were prepared. Every third section was collected on a poly-L-lysine-coated slide.

To assess cardiac lipofuscin accumulation, unstained cross-sections of hearts and proximal great vessels were examined by light microscopy for the presence of yellow-brown lipofuscin pigment granules. We have previously reported the identification of these yellow-brown granules as lipofuscin using a series of histochemical stains (13). Some sections were also examined with a melanin-specific stain and an iron-specific stain to rule out the presence of other pigments. Five structural sites were examined in each mouse heart for the presence of lipofuscin: the aortic valve leaflets, aortic wall, and ostia of the coronary arteries (AORV); mitral valve leaflets (MITV); tricuspid valve leaflets (TRIV); pulmonary valve leaflets (PULV); and the endocardium of the four cardiac chambers, including connective tissue associated with the aortic root anulus (ENDO). The presence of lipofuscin in any one of these five sites was defined as lipofuscin-positive. The amount of cardiac lipofuscin within each site was estimated using the following scoring system: $0=$ complete absence of lipofuscin; 1 = presence of lipofuscin in one section; 2 = presence of lipofuscin in two to three sequential sections; 3 = presence of lipofuscin in four or more sequential sections.

To assess aortic fatty streak lesion development, all sections were stained with oil red $\mathrm{O}$ and quantitatively examined for lipid deposition in the wall of the aortic root as previously described (15-17).

Statistical analysis. Student's $t$ test, correlation, and chi-square analyses were performed using software for the Macintosh (Statview II; Abacus Concepts, Inc., Berkeley, CA). The log of the odds score was determined using MAPMAKER/QTL software (provided by Drs. S. Lincoln and E. Lander, Massachusetts Institute of Technology, Cambridge, MA) as previously described (18).

\section{Results}

Histologic characterization and distribution of cardiac lipofus$\mathrm{cin}$. The results of a series of histochemical stains used to characterize cardiac lipofuscin are listed in Table I. These data are most consistent with the characteristics of lipofuscin/ceroid pigment. In unstained sections, the pigment appeared as brown, irregularly-shaped granules. The pigment stained slightly positive for the presence of lipid and positive for aldehydes. Although the pigment we observed did not exhibit autofluorescence, a typical property of lipofuscin, others have described the presence of nonfluorescing lipofuscin in spleen cells (19). The absence of this property may be related to the degree of oxidation or polymerization of lipofuscin components. The negative results for iron and melanin staining demonstrate that the pigment is not hemosiderin or melanin.

The distribution of cardiac lipofuscin in mice appears to be similar to that observed in humans (10). The deposition of lipofuscin in murine cardiac tissue is shown in Fig. 1. The

Table I. Characteristics of Cardiac Lipofuscin in the Mouse

\begin{tabular}{ll}
\hline \multicolumn{1}{c}{ Method of analysis } & \multicolumn{1}{c}{ Result } \\
\hline Color (unstained section) & Yellow-brown \\
Autofluorescence & Negative \\
Oil red O staining & Faintly positive \\
Periodic acid-Schiff reaction & Positive* \\
Ziehl-Neelsen staining & Positive/negative* \\
Schmorl's reaction & Positive* \\
Prussian blue iron staining & Negative \\
Melanin staining & Negative
\end{tabular}

* Reported previously by Mehrabian et al. (13). predominant site of lipofuscin accumulation is the aortic valve leaflet (Fig. $1 A$ ). However, the pigment can be observed in the mitral valve (Fig. $1 F$ ), tricuspid valve (not shown), and pulmonary valve (Fig. $1 E$ ) leaflets as well. The endocardium of the four cardiac chambers (Fig. $1, B$ and $D$ ), the ostia of the coronary arteries (Fig. 1, $B$ and $D$ ), and the connective tissue of the aortic root anulus (not shown) are also common sites for lipofuscin accumulation. Less frequently, lipofuscin can be found in the intimal, medial, and adventitial layers of the aortic root (Fig. 1C).

Genetic control of cardiac lipofuscin in mice. To investigate the role of genetic factors in cardiac lipofuscin formation, we surveyed several common inbred strains of mice for the presence of this trait ( Table II). The incidence of cardiac lipofuscin among the strains varied from 0 to $100 \%$. In chow-fed animals, a high incidence $(100 \%)$ of cardiac lipofuscin was observed for the C57BL/6J strain and the congenic strain, B6.C.H-25c, which is identical with $\mathrm{C} 57 \mathrm{BL} / 6 \mathrm{~J}$ except for a small region of mouse chromosome 1 (14). Both of the SM/J mice observed had cardiac lipofuscin, while only one out of four NZB/B1NJ mice were positive for lipofuscin. None of the chow-fed $\mathrm{C} 3 \mathrm{H} /$ $\mathrm{HeJ}, \mathrm{BALB} / \mathrm{cJ}, \mathrm{A} / \mathrm{J}$, or MRL/MPJ mice examined were cardiac lipofuscin positive.

The incidence and distribution of cardiac lipofuscin was dependent, in part, upon diet. The feeding of a diet high in cocoa butter, cholesterol, and cholic acid (ATH diet) for $15 \mathrm{wk}$ increased the overall incidence of lipofuscin in two unrelated strains, BALB/cJ (13\%) and $\mathrm{C} 3 \mathrm{H} / \mathrm{HeJ}(35 \%)$, relative to chow feeding (Table II). The strains that exhibited high incidence of cardiac lipofuscin when fed chow (the C57BL substrains and SM/J strain) also had high incidence after ATH feeding. However, the A/J and MRL strains, which had no incidence of lipofuscin on chow, remained resistant to pigment deposition on the ATH diet. In addition to the effect of diet on total incidence of cardiac lipofuscin, there was a strain-specific trend toward increased incidence at particular cardiac structural sites after 15 weeks of ATH feeding (Table III). In the C57BL/6J strain, which exhibited $100 \%$ total incidence of cardiac lipofuscin whether the mice were fed chow or ATH diet, all of the mice examined had an abundance (mean score $=3$ ) of lipofuscin in the aortic, mitral, and tricuspid valve leaflets, as well as the endocardium of the cardiac chambers. In the pulmonary valves, the incidence of lipofuscin was very low $(1 / 11$ mice) in chow-fed animals, but increased (12/63 mice) in ATH-fed mice. In the $\mathrm{C} 3 \mathrm{H} / \mathrm{HeJ}$ strain, feeding of the ATH diet induced a moderate incidence of lipofuscin in the pulmonary valves ( $8 / 23$ mice $)$ and low incidence in the aortic valves (2/23 mice); no lipofuscin was observed at any other site. Among the lipofuscin-positive $\mathrm{C} 3 \mathrm{H} / \mathrm{HeJ}$ mice, in contrast to the C57BL/6J mice, $100 \%$ incidence of pigment ( $8 / 8$ mice) was observed in the pulmonary valves and the deposits were relatively large (score $=3$, data not shown). In ATH-fed BALB/cJ mice, the pigment distribution (based on only two mice with lipofuscin) reflected that of the C57BL mice. Thus, $2 / 2$ lipofuscin-positive mice exhibited pigment deposition in the aortic, mitral, and tricuspid valves as well as the endocardium, but not in the pulmonary valves. Furthermore, the relative abundance of cardiac pigment in the lipofuscin-positive BALB $/ \mathrm{cJ}$ mice (score $=3$ at all sites except the pulmonary valves; data not shown) was similar to that observed in the C57BL $/ 6 \mathrm{~J}$ mouse hearts ( score $=3$ at all sites except the pulmonary valves). 

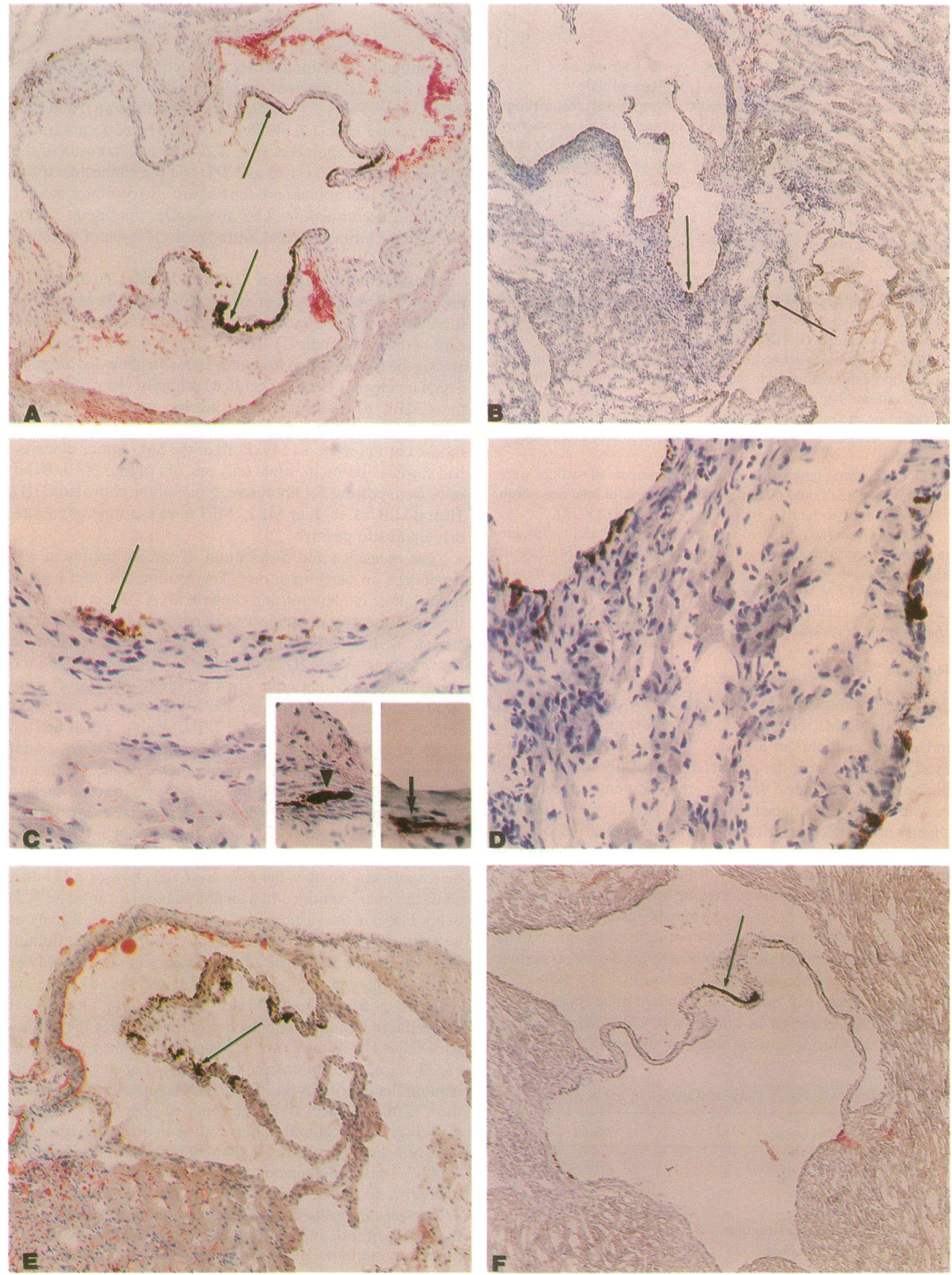

Figure 1. Lipofuscin deposition in mouse cardiac tissues. Sections were stained with hematoxylin and oil red O. $(A)$ Lipofuscin on ventricular (inflow) surfaces of aortic valve leaflets (arrows) (red areas represent atheromatous lesions containing lipid and staining with oil red $O$ ). (B) Low power view of the ostia of coronary artery (top arrow) and adjacent endocardium of right atrium (bottom arrow) showing lipofuscin deposition. $(C)$ Lipofuscin deposition in the intima of aortic wall; insets show lipofuscin deposition in aortic media (arrowhead) and adventitia $($ arrow). (D) Higher magnification of regions shown in $B$. $(E)$ Lipofuscin deposition in ventricular (inflow) surface of pulmonary valve (arrow). $(F)$ Lipofuscin deposition on left atrial surface of anterior mitral valve leaflet (arrow) $(A, \times 40 ; B, \times 40 ; C, \times 160 ; D, \times 160 ; E, \times 80 ; F, \times 40)$. 
Table II. Strain Distribution of Cardiac Lipofuscin Among Inbred Strains of Mice Fed Either Chow or the ATH Diet for 15 wk

\begin{tabular}{lcc}
\hline & \multicolumn{2}{c}{ Incidence of cardiac lipofuscin } \\
\cline { 2 - 3 } \multicolumn{1}{c}{ Strain } & \multicolumn{1}{c}{ Chow } & ATH \\
\hline C57BL/6J & $27 / 27^{*}(100 \%)$ & $112 / 112(100 \%)$ \\
B6.C. $H^{-25 c}$ & $7 / 7(100 \%)$ & $9 / 9(100 \%)$ \\
C57BL/10ScSnA & ND & $6 / 6(100 \%)$ \\
SM/J & $2 / 2(100 \%)$ & $2 / 3(66 \%)$ \\
NZB/B1NJ & $1 / 4(25 \%)$ & $1 / 3(33 \%)$ \\
C3H/DiSnA & ND & $2 / 6(33 \%)$ \\
C3H/HeJ & $0 / 7(0 \%)$ & $8 / 23(35 \%)$ \\
BALB/cJ & $0 / 4(0 \%)$ & $2 / 15(13 \%)$ \\
A/J & $0 / 4(0 \%)$ & ND \\
MRL/MPJ-+/+ & $0 / 9(0 \%)$ & $0 / 18(0 \%)$ \\
MRL/MPJ-lpr/lpr & $0 / 7(0 \%)$ & $0 / 14(0 \%)$ \\
& & \\
\hline
\end{tabular}

* Fraction of lipofuscin-positive mice/total number of mice in group.

The relative resistance to cardiac lipofuscin deposition observed in the pulmonary valves of $\mathrm{C} 57 \mathrm{BL} / 6 \mathrm{~J}$ mice was also observed in other C57BL substrains (Table IV). Thus, although there was $100 \%$ incidence of lipofuscin at all other sites examined, there was an absence of pigment at the pulmonary valves of B6.C. $\mathrm{H}-25^{\mathrm{c}}$ and C57BL/10ScSnA mice. Similarly, in a substrain of $\mathrm{C} 3 \mathrm{H}, \mathrm{C} 3 \mathrm{H} / \mathrm{DiSnA}$, the distribution of pigment in lipofuscin-positive mice was similar to that in $\mathrm{C} 3 \mathrm{H} / \mathrm{HeJ}$ mice. Thus, among the lipofuscin-positive $\mathrm{C} 3 \mathrm{H} / \mathrm{DiSnA}$ mice, lipofuscin was observed in the pulmonary ( $100 \%$ or $2 / 2$ mice) and the aortic ( $1 / 2$ mice) valves, but was absent from all other sites. No cardiac lipofuscin was observed in any of the MRL mice.

The relative amount and distribution of murine cardiac lipofuscin did not appear to be related to sex. For example, in the $\mathrm{C} 57 \mathrm{BL} / 6 \mathrm{~J}$ strain, both male and female mice had wide- spread cardiac lipofuscin deposition. Similarly, cardiac lipofuscin in humans is not associated with sex (10). It is likely that age contributes to lipofuscin deposition, but this aspect was not examined.

Cardiac lipofuscin cosegregates with the albino locus on mouse chromosome 7. To understand the inheritance of cardiac lipofuscin in mice, a cross between B6.C. $H-25^{c}$ (high incidence of cardiac lipofuscin) and BALB/cJ (low incidence of cardiac lipofuscin) was constructed and studied. The incidence of cardiac lipofuscin in the two parental strains and the F1 and F2 progeny is shown in Table $\mathrm{V}$. Lipofuscin deposition was observed in all $(9 / 9)$ of the F1 hybrid mice and approximately three fourths $(44 / 60)$ of the F2 hybrids. These data indicate that the pattern of inheritance of cardiac lipofuscin is autosomal dominant.

A comparison of the segregation pattern of cardiac lipofuscin with the albino locus $(c)$ on mouse chromosome 7 revealed complete concordance. Thus, all F2 mice that were homozygous $(c / c)$ for the BALB/cJ allele at the albino locus lacked lipofuscin, whereas all mice that were either heterozygous $(+$ / c) or homozygous $(+/+)$ for the $\mathrm{C} 57 \mathrm{BL} / 6 \mathrm{~J}$ allele contained lipofuscin (Table IV). The segregation pattern of the albino locus was determined by coat color as previously described (20). These results indicate that the genetic determinant of lipofuscin is tightly linked to, or identical with, the albino locus (LOD score $=76)$.

The tyrosinase gene determines cardiac lipofuscin. The albino locus encodes tyrosinase, the rate-limiting enzyme in melanin synthesis. To test whether the tyrosinase gene itself, rather than a linked gene, was responsible for the control of cardiac lipofuscin formation, we used a strain of C57BL/6J, designated C57BL/ $6 \mathrm{~J}-c^{2 J / 2 J}$, that had incurred a spontaneous mutation of the tyrosinase gene. Homozygotes for the $c^{2 J}$ allele reflect the classical albino system in which tyrosinase activity is absent $(21,22)$ and melanosome size is reduced (23). Both homozygous $\left(c^{2 J / 2 J}\right)$ and heterozygous $\left(c^{2 J /+}\right)$ animals were examined for the presence of cardiac lipofuscin (Table VI). All

Table III. Incidence, Distribution, and Quantity of Cardiac Lipofuscin in Female C57BL/6J, C3H/HeJ, and BALB/cJ Mouse Strains Fed Either Chow or the ATH Diet for 15 wk

\begin{tabular}{|c|c|c|c|c|c|c|}
\hline \multirow[b]{2}{*}{ Strain } & \multirow[b]{2}{*}{ Diet } & \multicolumn{5}{|c|}{ Incidence of cardiac lipofuscin } \\
\hline & & $\begin{array}{l}\text { AORV } \\
\text { (score) }\end{array}$ & $\begin{array}{l}\text { MITV } \\
\text { (score) }\end{array}$ & $\begin{array}{l}\text { TRIV } \\
\text { (score) }\end{array}$ & $\begin{array}{l}\text { PULV } \\
\text { (score) }\end{array}$ & $\begin{array}{l}\text { ENDO } \\
\text { (score) }\end{array}$ \\
\hline \multirow[t]{2}{*}{$\mathrm{C} 57 \mathrm{BL} / 6 \mathrm{~J}$} & Chow & $\begin{array}{c}11 / 11^{*} \\
(3.0 \pm 0)^{\ddagger}\end{array}$ & $\begin{array}{c}11 / 11 \\
(3.0 \pm 0)\end{array}$ & $\begin{array}{c}11 / 11 \\
(3.0 \pm 0)\end{array}$ & $\begin{array}{c}1 / 11 \\
(0.3 \pm 0.3)\end{array}$ & $\begin{array}{c}11 / 11 \\
(3.0 \pm 0)\end{array}$ \\
\hline & ATH & $\begin{array}{c}63 / 63 \\
(3.0 \pm 0)\end{array}$ & $\begin{array}{c}63 / 63 \\
(3.0 \pm 0)\end{array}$ & $\begin{array}{c}63 / 63 \\
(3.0 \pm 0)\end{array}$ & $\begin{array}{c}12 / 63 \\
(0.6 \pm 0.2)\end{array}$ & $\begin{array}{c}63 / 63 \\
(3.0 \pm 0)\end{array}$ \\
\hline \multirow[t]{2}{*}{$\mathrm{C} 3 \mathrm{H} / \mathrm{HeJ}$} & Chow & $\begin{array}{c}0 / 7 \\
(0)\end{array}$ & $\begin{array}{l}0 / 7 \\
(0)\end{array}$ & $\begin{array}{l}0 / 7 \\
(0)\end{array}$ & $\begin{array}{r}0 / 7 \\
(0)\end{array}$ & $\begin{array}{l}0 / 7 \\
(0)\end{array}$ \\
\hline & ATH & $\begin{array}{c}2 / 23 \\
(0.3 \pm 0.1)\end{array}$ & $\begin{array}{l}0 / 23 \\
(0)\end{array}$ & $\begin{array}{l}0 / 23 \\
(0)\end{array}$ & $\begin{array}{c}8 / 23^{\S} \\
(1.0 \pm 0.3)\end{array}$ & $\begin{array}{l}0 / 23 \\
(0)\end{array}$ \\
\hline \multirow[t]{2}{*}{$\mathrm{BALB} / \mathrm{cJ}$} & Chow & $\begin{array}{c}0 / 4 \\
(0)\end{array}$ & $\begin{array}{l}0 / 4 \\
(0)\end{array}$ & $\begin{array}{l}0 / 4 \\
(0)\end{array}$ & $\begin{array}{l}0 / 4 \\
(0)\end{array}$ & $\begin{array}{l}0 / 4 \\
(0)\end{array}$ \\
\hline & ATH & $\begin{array}{c}2 / 15 \\
(0.4 \pm 0.3)\end{array}$ & $\begin{array}{c}2 / 15 \\
(0.4 \pm 0.3)\end{array}$ & $\begin{array}{c}2 / 15 \\
(0.4 \pm 0.3)\end{array}$ & $\begin{array}{l}0 / 15 \\
(0)\end{array}$ & $\begin{array}{c}2 / 15 \\
(0.4 \pm 0.3)\end{array}$ \\
\hline
\end{tabular}

* Fraction of lipofuscin-positive mice/total number of mice in group. ${ }^{\ddagger}$ Score (group mean \pm SEM) was determined as described in Methods.

${ }^{8}$ Chow vs ATH (PULV): $\chi=3.15, P<0.08$. 
Table IV. Cardiac Lipofuscin and Aortic Fatty Lesion Development in C57BL, C3H, BALB/cJ, and MRL Female Mice Fed an ATH Diet for 15 wk

\begin{tabular}{|c|c|c|c|c|c|c|}
\hline \multirow[b]{2}{*}{ Strain } & \multicolumn{5}{|c|}{ Cardiac lipofuscin } & \multirow{2}{*}{$\begin{array}{c}\text { Mean } \\
\text { aortic lesion } \\
\text { area }\left(\times 10^{3}\right)^{8}\end{array}$} \\
\hline & $\begin{array}{l}\text { AORV } \\
\text { (score) }\end{array}$ & $\begin{array}{l}\text { MITV } \\
\text { (score) }\end{array}$ & $\begin{array}{l}\text { TRIV } \\
\text { (score) }\end{array}$ & $\begin{array}{l}\text { PULV } \\
\text { (score) }\end{array}$ & $\begin{array}{l}\text { ENDO } \\
\text { (score) }\end{array}$ & \\
\hline $\mathrm{C} 57 \mathrm{BL} / 6 \mathrm{~J}$ & $\begin{array}{c}63 / 63^{*} \\
(3.0 \pm 0)^{\ddagger}\end{array}$ & $\begin{array}{r}63 / 63 \\
(3.0 \pm 0)\end{array}$ & $\begin{array}{r}63 / 63 \\
(3.0 \pm 0)\end{array}$ & $\begin{array}{c}12 / 63 \\
(0.6 \pm 0.2)\end{array}$ & $\begin{array}{r}63 / 63 \\
(3.0 \pm 0)\end{array}$ & $13.7+1.9$ \\
\hline B6.C. $H^{-25 c}$ & $\begin{array}{c}9 / 9 \\
(3.0 \pm 0)\end{array}$ & $\begin{array}{c}9 / 9 \\
(3.0 \pm 0)\end{array}$ & $\begin{array}{c}9 / 9 \\
(3.0 \pm 0)\end{array}$ & $\begin{array}{l}9 / 9 \\
(0)\end{array}$ & $\begin{array}{c}9 / 9 \\
(3.0 \pm 0)\end{array}$ & $21.8 \pm 4.5$ \\
\hline C57BL/10ScSnA & $\begin{array}{c}6 / 6 \\
(3.0 \pm 0)\end{array}$ & $\begin{array}{c}6 / 6 \\
(3.0 \pm 0)\end{array}$ & $\begin{array}{c}6 / 6 \\
(3.0 \pm 0)\end{array}$ & $\begin{array}{l}0 / 6 \\
(0)\end{array}$ & $\begin{array}{c}6 / 6 \\
(3.0 \pm 0)\end{array}$ & $17.8 \pm 6.2$ \\
\hline $\mathrm{C} 3 \mathrm{H} / \mathrm{HeJ}$ & $\begin{array}{c}2 / 23 \\
(0.3 \pm 0.1)\end{array}$ & $\begin{array}{l}0 / 23 \\
(0)\end{array}$ & $\begin{array}{l}0 / 23 \\
(0)\end{array}$ & $\begin{array}{c}8 / 23 \\
(1.0 \pm 0.3)\end{array}$ & $\begin{array}{l}0 / 23 \\
(0)\end{array}$ & $0.7 \pm 0.2^{11}$ \\
\hline C3H/DiSnA & $\begin{array}{c}1 / 6 \\
(0.5 \pm 0.5)\end{array}$ & $\begin{array}{l}0 / 6 \\
(0)\end{array}$ & $\begin{array}{l}0 / 6 \\
(0)\end{array}$ & $\begin{array}{c}2 / 6 \\
(1.0 \pm 0.6)\end{array}$ & $\begin{array}{l}0 / 6 \\
(0)\end{array}$ & $4.3 \pm 1.7^{\prime}$ \\
\hline $\mathrm{BALB} / \mathrm{cJ}$ & $\begin{array}{c}2 / 15 \\
(0.4 \pm 0.3)\end{array}$ & $\begin{array}{c}2 / 15 \\
(0.4 \pm 0.3)\end{array}$ & $\begin{array}{c}2 / 15 \\
(0.4 \pm 0.3)\end{array}$ & $\begin{array}{l}0 / 15 \\
(0)\end{array}$ & $\begin{array}{c}2 / 15 \\
(0.4 \pm 0.3)\end{array}$ & $2.4 \pm 1.6^{\| \prime}$ \\
\hline MRL/MPJ-+/+ & $\begin{array}{r}0 / 5 \\
(0)\end{array}$ & $\begin{array}{l}0 / 5 \\
(0)\end{array}$ & $\begin{array}{l}0 / 5 \\
(0)\end{array}$ & $\begin{array}{l}0 / 5 \\
(0)\end{array}$ & $\begin{array}{l}0 / 5 \\
(0)\end{array}$ & $7.4 \pm 2.9$ \\
\hline MRL/MPJ-lpr/lpr & $\begin{array}{r}0 / 7 \\
(0)\end{array}$ & $\begin{array}{l}0 / 7 \\
(0)\end{array}$ & $\begin{array}{l}0 / 7 \\
(0)\end{array}$ & $\begin{array}{l}0 / 7 \\
(0)\end{array}$ & $\begin{array}{l}0 / 7 \\
(0)\end{array}$ & $2.6 \pm 1.0^{\| 1}$ \\
\hline
\end{tabular}

* Fraction of lipofuscin-positive mice/total number of mice in group. ${ }^{\ddagger}$ Score (group mean \pm SEM) was determined as described in Methods. ${ }^{8}$ Lesion area (group mean $\pm \mathrm{SEM}, \mu \mathrm{m}^{2} /$ section) was determined as described in Methods. "Indicates significant difference compared to $\mathrm{C} 57 \mathrm{BL} / 6 \mathrm{~J}, P<0.004$. 'Indicates significant difference compared to $\mathrm{C} 57 \mathrm{BL} / 6 \mathrm{~J}, P<0.04$.

mice homozygous for the tyrosinase mutation lacked cardiac lipofuscin, while all mice heterozygous for the mutation contained cardiac lipofuscin. This experiment demonstrates that the tyrosinase gene directly affects cardiac lipofuscin deposition in the mouse.

Evidence for additional genes controlling cardiac lipofuscin. The data presented in Tables II-IV suggest that multiple genetic factors are likely to contribute to the incidence of cardiac lipofuscin among inbred strains. In particular, the strains $\mathrm{C} 3 \mathrm{H} / \mathrm{HeJ}$ and $\mathrm{C} 57 \mathrm{BL} / 6 \mathrm{~J}$ both contain a wild type tyrosinase allele, but they exhibit very different tissue distribution patterns and frequencies of cardiac lipofuscin development. To further test whether other genetic factors, in addition to the tyrosinase gene, influence the deposition of cardiac lipofuscin, we examined the occurrence of lipofuscin in C57BL/6J (B) $\times \mathrm{C} 3 \mathrm{H} / \mathrm{HeJ}(\mathrm{H})$ recombinant-inbred (RI) strains (Table VII). Cardiac lipofuscin was observed in $100 \%$ of (BXH) RI strains 11 and 14. All other (BXH) RI strains exhibited variable penetrance of lipofuscin expression. In addition, the pat- tern of tissue distribution, as well as the relative abundance of lipofuscin, varied from strain to strain. These data reveal significant differences in lipofuscin accumulation among RI strains derived from two nonalbino parental strains. This conclusively demonstrates that there are one or more genetic elements in addition to tyrosinase that regulate the expression of cardiac lipofuscin among inbred strains of mice.

A previous study with splenic lipofuscin indicated that certain mutations affecting intracellular organelles, including lysosomes and melanosomes, decreased lipofuscin deposition (24). We tested one such recessive mutant strain, beige ( $b g$ ), for effects on cardiac lipofuscin (Table VI). In contrast to splenic lipofuscin, neither homozygous nor heterozygous C57BL/6J-bg mice exhibited reduced cardiac lipofuscin development.

Cardiac lipofuscin and atherosclerosis susceptibility in mice. In addition to the effect on lipofuscin accumulation, 15wk feeding of the ATH diet results in fatty streak formation in the proximal aortas of certain strains of mice (15). These le-

Table V. Segregation of Cardiac Lipofuscin with the Albino (c) Locus on Mouse Chromosome 7

\begin{tabular}{lrc}
\hline \multicolumn{1}{c}{ Strain } & $c$ Locus & Incidence of cardiac lipofuscin \\
\hline B6.C. $H^{-25 c}(\mathrm{~B})$ & $+/+$ & $7 / 7^{*}(100 \%)$ \\
BALB/cJ $(\mathrm{C})$ & $c / c$ & $0 / 4(0 \%)$ \\
$(\mathrm{BXC}) \mathrm{F} 1$ & $c /+$ & $9 / 9(100 \%)$ \\
$(\mathrm{BXC}) \mathrm{F} 2$ & $c / c$ & $0 / 16(0 \%)$ \\
$(\mathrm{BXC}) \mathrm{F} 2$ & $c /+,+/+$ & $44 / 44(100 \%)$
\end{tabular}

* Fraction of lipofuscin-positive mice/total number of mice in group.

Table VI. Incidence of Cardiac Lipofuscin in Mutant C57BL/6J Mouse Sublines Carrying Either an Albino or Lysosomal Mutation

\begin{tabular}{cc}
\hline Strain & Incidence of cardiac lipofuscin \\
\hline $\mathrm{C} 57 \mathrm{BL} / 6 \mathrm{~J}-c^{2 \mathrm{~J} / 2 J}$ & $0 / 5^{*}(0 \%)$ \\
$\mathrm{C} 57 \mathrm{BL} / 6 \mathrm{~J}-c^{2 \mathrm{~J} /+}$ & $5 / 5(100 \%)$ \\
$\mathrm{C} 57 \mathrm{BL} / 6 \mathrm{~J}-b g / b g$ & $5 / 5(100 \%)$ \\
$\mathrm{C} 57 \mathrm{BL} / 6 \mathrm{~J}-b g /+$ & $5 / 5(100 \%)$
\end{tabular}

* Fraction of lipofuscin-positive mice/total number of mice in group. 
sions are characterized by an accumulation of lipoproteins, intimal macrophages and foam cells (13), and cholesterol crystals (25). As with lipofuscin, the relative susceptibility of different strains of mice to lesion development is genetically determined. For example, C57BL strains are highly susceptible, while $\mathrm{C} 3 \mathrm{H} / \mathrm{HeJ}$ and $\mathrm{BALB} / \mathrm{cJ}$ strains are relatively resistant to lesion formation (15). To test whether common pathways may contribute to fatty streak and lipofuscin development, several mouse strains were characterized for both traits after 15-wk feeding of the ATH diet. Mean aortic lesion area was correlated with lipofuscin incidence $(r=0.94)$ (Table IV). The C57BL substrains, which had $100 \%$ incidence of cardiac lipofuscin, were the most susceptible strains to fatty streak development $\left(\right.$ mean lesion area $=17.8 \times 10^{3} \mu \mathrm{m}^{2} /$ section $)$. In the $\mathrm{C} 3 \mathrm{H} / \mathrm{HeJ}$ and $\mathrm{C} 3 \mathrm{H} / \mathrm{DiSnA}$ strains, which exhibited moderate incidence of cardiac lipofuscin when fed the ATH diet, the mean lesion areas for each of the strains was significantly less $(P<0.001$ and $P<0.04$, respectively) relative to C57BL strains. The BALB/cJ strain, which had lipofuscin in only 2/ 15 mice, also exhibited significant resistance to lesion formation $(P<0.004)$ relative to $\mathrm{C57BL}$ mice. The two MRL strains, which exhibited no lipofuscin, were relatively resistant to lesion formation.

Based on these observations, as well as data reported by others suggesting that both lipofuscin (1-9) and fatty streak (26) formation involve lipid oxidation, we hypothesized that these processes may exhibit coordinate control. To investigate this hypothesis, we examined the concordance of lipofuscin and fatty streak formation in ATH-fed BALB/cJ mice, which exhibit incomplete penetrance of both traits. 2/15 BALB/cJ mice had cardiac lipofuscin and both of these mice developed extensive lesions $\left(18 \times 10^{3} \mu \mathrm{m}^{2} /\right.$ section $)$; none of the remaining mice had cardiac lipofuscin or fatty streak development (Fig. 2). This result is highly significant $(P<0.0001)$ and suggests strongly that these two traits are influenced by common processes, quite possibly relating to oxidative stress (see Discussion). Since the BALB/cJ mice examined are genetically identical, the incidence of both lipofuscin and fatty streaks in a fraction of the animals must result from unknown developmental differences or environmental influences. A better understanding of these functions would be of considerable interest.

The genetic relationship between cardiac lipofuscin and atherosclerotic lesion development was examined in the (BXH) set of RI strains. Quantitative assessment of aortic fatty streak formation in the (BXH) RI strains revealed nonparental phenotypes (Table VII), indicating the involvement of multiple independent genetic factors or a major genetic effect with modi-

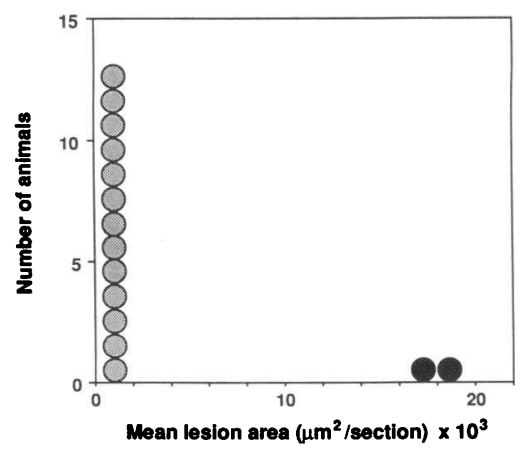

Figure 2. Coincidence of cardiac lipofuscin and fatty streak formation in BALB/cJ mice. Mice that were positive for cardiac lipofuscin $(\bullet)$ developed extensive fatty streaks, whereas none of the lipofuscin-negative $(0)$ mice had evidence of fatty streak formation. fying genetic factors. The results of our quantitation of mean aortic lesion area by planimetry are in general agreement with previous results obtained using a less quantitative method (16), although there appear to be significant differences for RI strains (BXH)-7 and (BXH)-10. Clearly, some of the genetic factors contributing to lipofuscin formation and aortic fatty streak development act independently. For example, RI strains (BXH)-8 and (BXH)-19 exhibited little or no lipofuscin deposition but were quite susceptible to lesion formation. Furthermore, there was no obvious relationship between fatty streak formation and lipofuscin deposition at any particular cardiac site. These results indicate that multiple genetic factors contribute to both fatty streak development and lipofuscin deposition, and that among the (BXH) set of RI strains, they are at least partially independent. Thus, although the genetic studies with $\mathrm{BALB} / \mathrm{cJ}$ and $\mathrm{C57BL} / 6 \mathrm{~J}$ mice clearly indicate that lipofuscin and fatty streak development are influenced by a common process, our studies with the (BXH) set of RI strains indicate that additional, independent genetic factors can also contribute to the two traits.

\section{Discussion}

Our results clearly indicate that cardiac lipofuscin deposition is determined, in part, by genetic factors. A number of inbred strains of mice were examined and found to differ in both the levels and distribution of cardiac lipofuscin. For example, strain C57BL/6J and related strains exhibited $100 \%$ incidence, whereas other strains exhibited lower incidence or complete absence of cardiac lipofuscin. One of the genetic factors responsible for these observed differences is the tyrosinase gene. Thus, a cross between a substrain of C57BL/6J (100\% incidence of lipofuscin) and strain BALB/cJ (0\% incidence of lipofuscin when maintained on a chow diet) showed that cardiac lipofuscin is inherited as a dominant Mendelian trait that cosegregates with the albino $(c)$ locus encoding tyrosinase. A direct role for the tyrosinase gene, rather than a separate but tightly linked gene, in determining lipofuscin deposition was demonstrated by the observation that $\mathrm{C} 57 \mathrm{BL} / 6 \mathrm{~J}-c^{2 J} / c^{2 J}$ mice, which carry a spontaneous tyrosinase gene mutation, lacked cardiac lipofuscin. Certain nonalbino strains, such as $\mathrm{C} 3 \mathrm{H} / \mathrm{HeJ}$, also exhibited low levels of cardiac lipofuscin, suggesting that additional genetic factors can also contribute to lipofuscin deposition. This was demonstrated in a cross between strain $\mathrm{C} 3 \mathrm{H} / \mathrm{HeJ}$ (low incidence) and C57BL/6J (100\% incidence), in which progeny mice showed a range of lipofuscin levels. In contrast to the simple, Mendelian inheritance pattern of lipofuscin in (BXC) mice, the (BXH) mice revealed a complex inheritance pattern, indicating the involvement of two or more genes in lipofuscin deposition.

Previous studies have revealed genetic differences in the occurrence of splenic lipofuscin in mice, with strain C57BL/6J being unusually susceptible $(19,27)$. In contrast to cardiac lipofuscin, the occurrence of splenic lipofuscin in C57BL/6J and related strains was only $10-50 \%$, making genetic analysis difficult. However, analysis of $\mathrm{C} 57 \mathrm{BL} / 10 \mathrm{ScSn}$ mice, congenic for the $c$ locus, suggested that the albino locus was associated with differences in the incidence of splenic lipofuscin (12). The finding of similar patterns of splenic and cardiac lipofuscin among certain strains, and the involvement of tyrosinase in lipofuscin deposition in both tissues, suggests that the genetic 
Table VII. Independent Segregation of Cardiac Lipofuscin and Aortic Fatty Lesion Development in Female C57BL/6J (B) $\times C 3 H / H e J(H)$ RI Mouse Strains Fed an ATH Diet for 15 wk

\begin{tabular}{|c|c|c|c|c|c|c|c|}
\hline \multirow[b]{2}{*}{ Strain } & \multicolumn{6}{|c|}{ Cardiac lipofuscin } & \multirow{2}{*}{$\begin{array}{c}\text { Mean } \\
\text { aortic lesion } \\
\text { area }\left(\times 10^{3}\right)^{8}\end{array}$} \\
\hline & $\begin{array}{l}\text { AORV } \\
\text { (score) }\end{array}$ & $\begin{array}{l}\text { MITV } \\
\text { (score) }\end{array}$ & $\begin{array}{l}\text { TRIV } \\
\text { (score) }\end{array}$ & $\begin{array}{l}\text { PULV } \\
\text { (score) }\end{array}$ & $\begin{array}{l}\text { ENDO } \\
\text { (score) }\end{array}$ & Any site & \\
\hline $\mathrm{C} 57 \mathrm{BL} / 6 \mathrm{~J}$ & $63 / 63^{*}$ & $63 / 63$ & $63 / 63$ & $12 / 63$ & $63 / 63$ & $63 / 63$ & $13.7 \pm 1.9$ \\
\hline (B) & $(3.0 \pm 0)$ & $(3.0 \pm 0)$ & $(3.0 \pm 0)$ & $(0.6 \pm 0.2)$ & $(3.0 \pm 0)$ & & \\
\hline $\mathrm{C} 3 \mathrm{H} / \mathrm{HeJ}$ & $2 / 23$ & $0 / 23$ & $0 / 23$ & $8 / 23$ & $0 / 23$ & $8 / 23$ & $0.7 \pm 0.2$ \\
\hline$(\mathrm{H})$ & $(0.3 \pm 0.1)$ & $(0)$ & $(0)$ & $(1.0 \pm 0.3)$ & $(0)$ & & \\
\hline \multicolumn{8}{|c|}{ (BXH) RI strains: } \\
\hline (BXH)-3 & $\begin{array}{c}3 / 8 \\
(1.1 \pm 0.6)\end{array}$ & $\begin{array}{c}2 / 8 \\
(0.8 \pm 0.5)\end{array}$ & $\begin{array}{c}4 / 8 \\
(1.5 \pm 0.6)\end{array}$ & $\begin{array}{c}3 / 8 \\
(1.1 \pm 0.6)\end{array}$ & $\begin{array}{c}3 / 8 \\
(1.1 \pm 0.6)\end{array}$ & $6 / 8$ & $2.5 \pm 0.5$ \\
\hline$(\mathrm{BXH})-4$ & $\begin{array}{c}2 / 8 \\
(0.8 \pm 0.5)\end{array}$ & $\begin{array}{c}4 / 8 \\
(1.5 \pm 0.6)\end{array}$ & $\begin{array}{c}6 / 8 \\
(2.0 \pm 0.5)\end{array}$ & $\begin{array}{c}2 / 8 \\
(0.8 \pm 0.5)\end{array}$ & $\begin{array}{c}6 / 8 \\
(2.3 \pm 0.5)\end{array}$ & $7 / 8$ & $0.4 \pm 0.1$ \\
\hline$(\mathrm{BXH})-6$ & $\begin{array}{r}0 / 4 \\
(0)\end{array}$ & $\begin{array}{l}0 / 4 \\
(0)\end{array}$ & $\begin{array}{c}1 / 4 \\
(0.8 \pm 0.8)\end{array}$ & $\begin{array}{l}0 / 4 \\
(0)\end{array}$ & $\begin{array}{c}1 / 4 \\
(0.8 \pm 0.8)\end{array}$ & $1 / 4$ & $0.6 \pm 0.2$ \\
\hline$(\mathrm{BXH})-7$ & $\begin{array}{c}1 / 8 \\
(0.3 \pm 0.3)\end{array}$ & $\begin{array}{c}3 / 8 \\
(0.9 \pm 0.5)\end{array}$ & $\begin{array}{c}3 / 8 \\
(1.1 \pm 0.6)\end{array}$ & $\begin{array}{l}0 / 8 \\
(0)\end{array}$ & $\begin{array}{c}7 / 8 \\
(2.6 \pm 0.4)\end{array}$ & $7 / 8$ & $0.6 \pm 0.6$ \\
\hline$(\mathrm{BXH})-8$ & $\begin{array}{r}0 / 3 \\
(0)\end{array}$ & $\begin{array}{l}0 / 3 \\
(0)\end{array}$ & $\begin{array}{l}0 / 3 \\
(0)\end{array}$ & $\begin{array}{l}0 / 3 \\
(0)\end{array}$ & $\begin{array}{l}0 / 3 \\
(0)\end{array}$ & $0 / 3$ & $24.4 \pm 9.8$ \\
\hline$(\mathrm{BXH})-9$ & $\begin{array}{r}0 / 7 \\
(0)\end{array}$ & $\begin{array}{c}1 / 7 \\
(0.1 \pm 0.1)\end{array}$ & $\begin{array}{c}1 / 7 \\
(0.4 \pm 0.4)\end{array}$ & $\begin{array}{c}1 / 7 \\
(0.4 \pm 0.4)\end{array}$ & $\begin{array}{c}2 / 7 \\
(0.9 \pm 0.6)\end{array}$ & $2 / 7$ & $0.3 \pm 0.1$ \\
\hline$(\mathrm{BXH})-10$ & $\begin{array}{r}0 / 5 \\
(0)\end{array}$ & $\begin{array}{l}0 / 5 \\
(0)\end{array}$ & $\begin{array}{c}3 / 5 \\
(1.8 \pm 0.7)\end{array}$ & $\begin{array}{l}0 / 5 \\
(0)\end{array}$ & $\begin{array}{c}4 / 5 \\
(2.4 \pm 0.6)\end{array}$ & $4 / 5$ & $1.8 \pm 1.4$ \\
\hline$(\mathrm{BXH})-11$ & $\begin{array}{c}9 / 9 \\
(3.0 \pm 0)\end{array}$ & $\begin{array}{c}9 / 9 \\
(3.0 \pm 0)\end{array}$ & $\begin{array}{c}9 / 9 \\
(3.0 \pm 0)\end{array}$ & $\begin{array}{c}1 / 9 \\
(0.3 \pm 0.3)\end{array}$ & $\begin{array}{c}9 / 9 \\
(3.0 \pm 0)\end{array}$ & $9 / 9$ & $7.3 \pm 1.0$ \\
\hline$(\mathrm{BXH})-14$ & $\begin{array}{c}3 / 7 \\
(1.3 \pm 0.6)\end{array}$ & $\begin{array}{c}5 / 7 \\
(2.1 \pm 0.6)\end{array}$ & $\begin{array}{c}5 / 7 \\
(2.1 \pm 0.6)\end{array}$ & $\begin{array}{c}1 / 7 \\
(0.4 \pm 0.4)\end{array}$ & $\begin{array}{c}5 / 7 \\
(2.6 \pm 0.4)\end{array}$ & $7 / 7$ & $3.4 \pm 1.6$ \\
\hline$(\mathrm{BXH})-19$ & $\begin{array}{r}0 / 6 \\
(0)\end{array}$ & $\begin{array}{l}0 / 7 \\
(0)\end{array}$ & $\begin{array}{c}1 / 7 \\
(0.3 \pm 0.3)\end{array}$ & $\begin{array}{l}0 / 7 \\
(0)\end{array}$ & $\begin{array}{c}2 / 7 \\
(0.9 \pm 0.6)\end{array}$ & $2 / 7$ & $13.1 \pm 3.2$ \\
\hline
\end{tabular}

\footnotetext{
${ }^{*}$ Fraction of lipofuscin-positive mice/total number of mice in group. $\quad{ }^{\ddagger}$ Score (group mean \pm SEM) was determined as described in Methods.
}

$\$$ Lesion area (group mean $\pm \mathrm{SEM}, \mu \mathrm{m}^{2} /$ section) was determined as described in Methods.

factors influencing lipofuscin deposition act systemically. However, the much higher incidence of cardiac than splenic lipofuscin in C57BL/6J-related strains, and the finding that the $b g$ mutation did not discernibly affect cardiac lipofuscin whereas it abolished splenic lipofuscin, argue for tissue-specific influences as well.

Tyrosinase is the rate-limiting enzyme in melanin synthesis and is unusual in that it can use three different substrates to catalyze three different oxidation reactions in the melanin biosynthetic pathway (28-34). Lipofuscin is not known to be an intermediate or alternative product of the melanin synthetic pathway but some evidence suggests that the production of free radical species during melanin formation (35) may lead to lipofuscin production under certain conditions $(36,37)$. For example, studies of photoreceptors in crayfish indicate that tyrosinase is a mediator in the conversion of degraded membrane into lipofuscin granules (38). It is noteworthy that the expression of tyrosinase does not appear to be restricted to melanocytes (34) and is subject to complex transcriptional and posttranscriptional regulation (39-41).

Lipofuscin is frequently associated with atherosclerotic lesions (11), and it has been proposed that the pigment may participate in the disease process $(42,43)$. Our results suggest a link between lipofuscin deposition and the development of aortic fatty streaks. Thus, the feeding of an atherogenic diet, required for fatty streak development in laboratory strains of mice, enhanced cardiac lipofuscin. Furthermore, a striking correlation between the occurrence of large fatty streaks and lipofuscin deposition was observed in BALB/cJ mice fed an atherogenic diet. Studies of a set of recombinant inbred strains derived from strains $\mathrm{C} 57 \mathrm{BL} / 6 \mathrm{~J}$ and $\mathrm{C} 3 \mathrm{H} / \mathrm{HeJ}$, however, indicated that at least some of the genetic factors contributing to fatty streak formation and lipofuscin deposition act independently. Accumulating evidence implicates lipid oxidation in the early stages of atherosclerosis (reviewed in references 26 and 44), and it is likely that the deposition of lipofuscin is also a reflection of oxidative stress. Thus, macrophages accumulate lipofuscin-like pigment when incubated with oxidized, low density lipoproteins or polyunsaturated fatty acids $(45,46)$. Under certain conditions, lipofuscin may represent a free radical trapping mechanism, protecting cells from oxidative damage (42) whereas, under other conditions, the pigment may exert proinflammatory effects (47). Whether lipofuscin promotes or retards fatty streak development, or is simply a reflection of oxidative stress, is an important question that remains to be addressed. The mouse model should be useful in testing potential pathophysiologic effects of cardiac lipofuscin accumulation. 


\section{Acknowledgments}

We thank Margarete Mehrabian for assistance with the construction of genetic crosses, Tom Drake for the use of a cryostat for histological analysis, and Craig Warden for help with statistical analysis.

This work was supported, in part, by National Institutes of Health grants HL-42488 and HL-30568.

\section{References}

1. Koobs, D. H., R. L. Schultz, and R. V. Jutzy. 1978. The origin of lipofuscin and possible consequences to the myocardium. Arch. Pathol. Lab. Med. 102:6668.

2. Sohal, R. S., and U. T. Brunk. 1990. Lipofuscin as an indicator of oxidative stress and aging. In Lipofuscin and Ceroid Pigments. E. A. Porta, editor. Plenum Press, New York. pp. 17-26.

3. Wolman, M. 1981. Factors affecting lipid pigment formation. In Age Pigments. R. S. Sohal, editor. Elsevier, North-Holland Biomedical Press, New York. pp. 265-281.

4. Sohal, R. S., M. R. Marzabadi, D. Galaris, and U. T. Brunk. 1988. Effect of ambient oxygen concentration on lipofuscin accumulation in cultured rat heart myocytes. A novel in vitro model of lipofuscinogenesis. Free Rad. Biol. Med. $6: 23-30$.

5. Marzabadi, M. R., R. S. Sohal, and U. T. Brunk. 1988. Effect of ferric iron and desferrioxamine on lipofuscin accumulation in cultured rat heart myocytes. Mech. Ageing Dev. 46:145-157.

6. Reddy, K., B. Fletcher, A. Tappel, and A. L. Tappel. 1973. Measurement and spectral characteristics of fluorescent pigments in tissues of rats as a function of dietary polyunsaturated fats and vitamin E. J. Nutr. 103:908-915.

7. Blackett, A. D., and D. A. Hall. 1981. Tissue vitamin E levels and lipofuscin accumulation with age in the mouse. J. Gerontol. 36:529-533.

8. Jain, S. K., S. N. Levine, J. Duett, and B. Hollier. 1991. Reduced vitamin E and increased lipofuscin products in erythrocytes of diabetic rats. Diabetes. 40:1241-1244.

9. Friede, R. L. 1962. The relation of the formation of lipofuscin to the distribution of oxidative enzymes in the human brain. Acta Neuropathol. 2:113-125.

10. Strehler, B. L., D. D. Mark, A. S. Mildvan, and M. V. Gee. 1959. Rate and

magnitude of age pigment accumulation in the human myocardium. J. Gerontol. 14:430-439.

11. Ball, R. Y., K. L. H. Carpenter, M. J. Mitchinson. 1987. What is the significance of ceroid in human atherosclerosis? Arch. Pathol. Lab. Med. 111:1134-1140.

12. Crichton, D. N., and J. G. M. Shire. 1982. Genetic basis of susceptibility to splenic lipofuscinosis in mice. Genet. Res. 39:275-285.

13. Mehrabian, M., L. L. Demer, and A. J. Lusis. 1991. Differential accumulation of intimal monocyte-macrophages relative to lipoproteins and lipofuscin corresponds to hemodynamic forces on cardiac valves in mice. Arterioscler. Thromb. 11:947-957.

14. Bailey, D. W. 1975. Genetics of histocompatibility in mice. Immunogenetics. 2:249-256.

15. Paigen, B., A. Morrow, P. A. Holmes, D. Mitchell, and R. A. Williams. 1987. Quantitative assessment of atherosclerotic lesions in mice. Atherosclerosis. 68:231-240.

16. Paigen, B., D. Mitchell, K. Reue, A. Morrow, A. J. Lusis, and R. C. LeBoeuf. 1987. Ath-1, a gene determining atherosclerosis susceptibility and high density lipoprotein levels in mice. Proc. Natl. Acad. Sci. USA. 84:3763-3767.

17. Qiao, J.-H., L. W. Castellani, M. C. Fishbein, and A. J. Lusis. 1993. Immune-complex-mediated vasculitis increases coronary artery lipid accumulation in autoimmune-prone MRL mice. Arterioscler. Thromb. 13:932-943.

18. Lander, E. S., and D. Botstein. 1989. Mapping Mendelian factors underlying quantitative traits using RFLP linkage maps. Genetics. 121:185-199.

19. Crichton, D. N., A. Busuttil, and W. H. Price. 1978. Splenic lipofuscinosis in mice. J. Pathol. 126:113-140.

20. Lyon, M. F., and A. G. Searle, editors. 1989. Genetic Variants and Strains of the Laboratory Mouse. 2nd ed. Oxford University Press, Oxford, United Kingdom.

21. Yokoyama, T., D. W. Silversides, K. G. Waymire, B. S. Kwon, T. Takeuchi, and P. A. Overbeek. 1990. Conserved cysteine to serine mutation in tyrosinase is responsible for the classical albino mutation in laboratory mice. Nucleic Acids Res. 18:7293-7298.

22. Townsend, D., C. J. Witkop, Jr., and J. Mattson. 1990. Tyrosinase subcel- lular distribution and kinetic parameters in wild type and $c$-locus mutant C57BL/6J mice. J. Exp. Zool. 216:113-119.

23. Granholm, N. H., R. A. Japs, and K. E. Kappenman. 1990. Differentiation of hairbulb pigment cell melanosomes in compound agouti and albino locus mouse mutants $\left(\mathrm{A}^{y}, a, c^{2 J} ; \mathrm{C} 57 \mathrm{BL} / 6 \mathrm{~J}\right)$. Pigm. Cell Res. 3:16-27.

24. Ahmed, F., and J. G. Shire. 1985. Lysosomal mutations inhibit lipofuscinosis of the spleen in C57BL mice. J. Hered. 76:311-312.

25. Kreuzer, J., M. B. Lloyd, D. Bok, G. M. Fless, A. M. Scanu, A. J. Lusis, and M. E. Haberland. 1993. Lipoprotein (a) displays increased accumulation compared to low density lipoprotein in the murine arterial wall. Chem. Phys. Lipids. in press.

26. Witztum, J. L., and D. Steinberg. 1991. Role of oxidized low density lipoprotein in atherogenesis. J. Clin. Invest. 88:1758-1792.

27. Crichton, D. N., A. Busuttil, and A. Ross. 1980. An ultrastructural study of murine splenic lipofuscinosis. J. Ultrastruct. Res. 72:130-140.

28. Hearing, V. J., and K. Tsukamoto. 1991. Enzymatic control of pigmentation in mammals. FASEB (Fed. Am. Soc. Exp. Biol.) J. 5:2902-2909.

29. Barton, D. E., B. S. Kwon, and U. Francke. 1988. Human tyrosinase gene, mapped to chromosome 11 (q14- < q21), defines second region of homology with mouse chromosome 7. Genomics. 3:17-24.

30. Shibahara, S., Y. Tomita, T. Sakakura, C. Nager, B. Chaudhuri, and R. Muller. 1986. Cloning and expression of cDNA encoding mouse tyrosinase. $\mathrm{Nu}$ cleic Acids Res. 14:2413-2427.

31. Winder, A. J. 1991. Expression of a mouse tyrosinase cDNA in 3T3 Swiss mouse fibroblasts. Biochem. Biophys. Res. Commun. 178:739-745.

32. Tanaka, S., H. Yamamoto, S. Takeuchi, and T. Takeuchi. 1990. Melanization in albino mice transformed by introducing cloned mouse tyrosinase gene. Development. 108:223-227.

33. Jimenez, M., K. Tsukamoto, and V. J. Hearing. 1991. Tyrosinases from two different loci are expressed by normal and by transformed melanocytes. $J$. Biol. Chem. 266:1147-1156.

34. Lowings, P., U. Yavuzer, and C. R. Goding. 1992. Positive and negative elements regulate a melanocyte-specific promoter. Mol. Cell. Biol. 12:36533662 .

35. Koga, S., M. Nakano, and S. Tero-Kubota. 1992. Generation of superoxide during the enzymatic action of tyrosinase. Arch. Biochem. Biophys. 292:570 575 .

36. Wood, J. M., and K. U. Schallreuter. 1991. Studies on the reactions between human tyrosinase, superoxide anion, hydrogen peroxide and thiols. Biochim. Biophys. Acta. 1074:378-385.

37. Katz, M. L., C. M. Drea, G. E. Eldred, H. H. Hess, and W. G. Robinson, Jr. 1986. Influence of early photoreceptor degeneration on lipofuscin in the retinal pigment epithelium. Exp. Eye Res. 43:561-573.

38. Schraermeyer, U., and H. Stieve. 1991. Peroxidase and tyrosinase are present in secondary lysosomes that degrade photosensory membranes of the Crayfish photoreceptor: possible role in pigment granule formation. Pigm. Cell Res. 4:163-171.

39. Halaban, R., and G. Moellmann. 1993. White mutants in mice shedding light on humans. J. Invest. Dermatol. 100:176S-185S.

40. Porter, S., and B. Mintz. 1991. Multiple alternatively-spliced transcripts of the mouse tyrosinase-encoding gene. Gene 97:277-282.

41. Ruppert, S., G. Muller, B. Kwon, and G. Schutz. 1988. Multiple transcripts of the mouse tyrosinase gene are generated by alternative splicing. $E M B O$ (Eur. Mol. Biol. Organ.) J. 7:2715-2722.

42. Armstrong, D. A. 1992. Oxidized LDL, ceroid, and prostaglandin metabolism in human atherosclerosis. Med. Hypotheses. 38:244-248.

43. Carpenter, K. L. H., R. Y. Ball, N. P. Carter, S. E. Woods, S. L. Hartley, S. Davies, J. H. Enright, and M. J. Mitchinson. 1990. Modulation of ceroid accumulation in macrophages in vitro. In Lipofuscin and Ceroid Pigments. E. A. Porta, editor. Plenum Press, New York. pp. 333-343.

44. Chisholm, G. M. III. 1991. Antioxidants and atherosclerosis: A current assessment. Clin. Cardiol. 14:I-25-30.

45. Ball, R. Y., J. P. Bindman, K. L. H. Carpenter, and M. J. Mitchinson. 1986. Oxidized low density lipoprotein induces ceroid accumulation by murine peritoneal macrophages in vitro. Atherosclerosis. 60:173-181.

46. Shimasaki, H., R. Maeba, and N. Ueta. 1990. Lipid peroxidation and storage of fluorescent products by macrophages in vitro as a model of ceroid-like pigment formation. In Lipofuscin and Ceroid Pigments, E. A. Porta, editor. Plenum Press, New York. pp. 323-330.

47. Kaya, M., D. P. Edward, H. Tessler, and R. L. Hendricks. 1992. Augmentation of intraocular inflammation by melanin. Invest. Ophthalmol. \& Vis. Sci. $33: 522-531$. 